\title{
BT Öğretmenlerinin Derslerinde Gerçekleştirdiği Etkinlikler, Bu Etkinliklerin Öğretim Programına Uygunluğu ve Gerekçeleri
}

\author{
IT Teachers' Activities in Their Courses, the Suitability of \\ These Activities to the Curriculum and the Reasons
}

\begin{abstract}
Kemal BİLİR*, Özgen KORKMAZ**, Recep ÇAKIR***
Öz: $\mathrm{Bu}$ araştırmanın amacı Bilişim Teknolojileri öğretmenlerinin derslerinde gerçekleştirdikleri etkinliklerin neler olduğunu ve bu etkinliklerin programa uygunluğunu belirlemektir. Araştırmanın çalışma grubunu 2016-2017 eğitim-öğretim yılında görev yapmakta olan 200 Bilişim Teknolojileri öğretmeni oluşturmaktadır. Araştırmada nicel araştırma yöntemlerinden betimsel tarama modeli tercih edilmiştir. Araştırmada kullanılan anketin hazırlama aşamasında uzman görüşleri de alınarak açık uçlu sorular sorulmuş ve elde edilen cevaplardan toplanan veriler anket haline getirilmiştir. Verilerin analizinde; frekans, aritmetik ortalama, yüzde, standart sapma, korelasyon, bağımsız örneklem t testi ve tek yönlü varyans analizleri yapılmıştır. Çalışma sonucunda öğretmenlerin gerçekleştirdikleri etkinliklerin temel konular üzerinde yoğunlaştığ ve bu etkinliklerin programa uygun şekilde gerçekleştirildiği sonucuna ulaşılmıştır.

Anahtar Kelimeler: Bilişim teknolojileri, BT öğretmeni, ders etkinlikleri, öğretim programı
\end{abstract}

\begin{abstract}
The purpose of this study was to determine the activities of Information Technology (IT) teachers in their courses and the appropriateness of these activities according to the curriculum. The sample of this study consists of the 200 teachers who serving in 2016-2017 educational year. Quantitative survey research method was conducted. While preparing the tool to collect data, open ended questions were asked to teachers by taking expert opinions and a questionnaire was formed according to the answers of the teachers. Frequencies, mean, percentage, standard deviation, correlation, independent sample t-test, One Way Anova analyses were run for analyzing data. As a result of the study, it was concluded that the activities carried out by the teachers were focused on the basic subjects and these activities were applied in accordance with the curriculum.
\end{abstract}

Keywords: Information technologies, IT teachers, teaching activities, curriculum

\section{Giriş}

Bilişim Teknolojileri (BT) günümüzde insan hayatının birçok bölümünde yer almaktadır. Hızlı ve kolay bir biçimde bilgiye ulaşma fırsatı sağladığından dolayı bireylerin teknoloji kullanma düzeyleri her geçen gün artmaktadır. Türkiye İstatistik Kurumu (TÜİK) araştırmasına göre internet ve bilgisayar kullanım oranları 2016 yılı Nisan ayında 16-74 yaş grubundaki kişilerde sıras ile $\% 61,2$ ve $\% 54,9$ olmuştur. Bu oranlar erkeklerde \%70,5 ve \%64,1 kadınlarda ise $\% 51,9$ ve $\% 45,9$ 'dur. Tüik verilerine göre internet ve bilgisayar kullanım oranları, 2015 yılında siras1 ile \%55,9 ve \%54,8 olduğu görülmektedir (TÜİK, 2016). Teknoloji, bilgiye ulaşmada daha fazla araştırma olanağı sunduğu için materyal olarak insanlara çok miktarda kaynak sağlamaktadır (Fahnoe ve Mishra, 2013). Her alanda var olan teknoloji eğitim alanında da vazgeçilmez bir unsurdur (Akkoyunlu ve Kurbanoğlu, 2003). Birleşmiş Milletler Eğitim Bilim

\footnotetext{
* Y. Lisans Öğrencisi, Amasya Üniversitesi Fen Bilimleri Enstitüsü Bilgisayar ve Öğretim Teknolojileri Eğitimi Anabilim Dal1, Amasya, Türkiye, ORCID: 0000-0002-7358-2561, e-posta: kemalbilir05@ gmail.com

** Doç. Dr., Amasya Üniversitesi Teknoloji Fakültesi, Bilgisayar Mühendisliği Bölümü, Amasya, Türkiye, ORCID: 0000-0003-4359-5692, e-posta: ozgenkorkmaz@gmail.com

*** Doç. Dr., Amasya Üniversitesi Eğitim Fakültesi Bilgisayar ve Öğretim Teknolojileri Eğitimi Bölümü, Amasya, Türkiye, ORCID: 0000-0002-2641-5007, e-posta: recepcakirt@gmail.com
} 
ve Kültür Örgütü (UNESCO)'de, eğitim ile ilgili bütün uygulamalarda BT'nin aktif olarak kullanımın hem bir firsat hem de bir gereklilik olduğunu ifade etmektedir (UNESCO, 2009, Akt: Topu 2012). Bu çerçevede eğitimde BT kullanımının Türkiye'de de bir ihtiyaç haline geldiğini söylemek mümkündür. Türkiye'de ortaöğretim kurumlarında görev yapan öğretmenlerin eğitimde bilgisayar kullanımı ve bilgisayarların öğretim programlarıyla entegrasyonu konusunda yetiştirilmesi amacı ile ilk kez öğretmen eğitimi 1985 yılında düzenlenmiş ve 225 öğretmen eğitilmiştir. Bu bağlamda daha sonraki yıllarda bilgisayarların eğitimde kullanımının yaygınlaştırılması için MEB üniversiteler ile işbirliğine gitmiş ve çeşitli okullardan öğretmenler için hizmet içi eğitim programları düzenlemiştir (Orhan ve Akkoyunlu, 2003). 1998-1999 eğitim-öğretim döneminden itibaren üniversitelerin eğitim fakültelerinde Bilgisayar ve Öğretim Teknolojileri Eğitimi (BÖTE) bölümleri açılmaya başlanmıştır. Bu bölümlerin açılması ile ilköğretim ve orta öğretim düzeyindeki eğitim kurumları için, temel mesleki beceri ve bilgileri kazanmış bilgisayar ve öğretim teknolojileri öğretmenleri yetiştirmek amaçlanmıştır (Eren ve Uluuysal, 2012). Eğitim ve öğretimde firsat eşitliğini sağlamak ve okullarda kullanılan teknolojiyi daha iyi hale getirmek amaciyla 2010 yılında Fırsatları Artırma ve Teknolojiyi İyileştirme Hareketi (FATİH Projesi), eğitimde teknoloji entegrasyonunun sağlanmasına dönük Türkiye'deki en kapsamlı proje olarak ortaya çıkmıştır. Halen yürütülmekte olan Fatih projesinin, eğitimde teknoloji kullanımını üst düzeye çıkaracak bir proje olarak BT derslerine de içerik ve işleniş bakımından büyük katkı sağlaması beklenmektedir. $\mathrm{Bu}$ proje kapsamında e-içerikler üretilmiş ve bu e-içeriklere öğretmen ve öğrencilerin kolayca ulaşabilmeleri için ortam hazırlanmaya çalışılmaktadır (Kurt, Kuzu, Dursun, Güllüpınar ve Gültekin, 2013).

ISTE'nin (International Society for Technology in Education) ortaya koyduğu 21. yy becerileri içerisinde önemli bir yere sahip olan BT yeterlilikleri evrensel düzeyde geliştirilmesinin kaçınılmaz olduğunu ortaya koymaktadır (ISTE, 2014). Bu doğrultuda BT dersleri Türkiye'de de eğitim programlarına girmiş ve halen ortaokul düzeyinde 5 . ve 6 . Sınıflarda zorunlu 7. ve 8. Sınıflarda seçmeli olmak üzere 2 saat okutulmaktadır (TTKB, 2016). Son yıllarda bu dersin içeriği ile ilgili tartışmalar yapılmaktadır ve bu derslere programlama içerikleri konması gündemdedir. Kodlama dersi ile öğrencilerde düşünme becerilerini geliştirmek amaçlanmıştır.

Kuşkusuz bu derslerin etkin olabilmesi, hem okullardaki donanım durumuna hem de öğretmenlerin gerçekleştirdikleri etkinliklere bağlıdır. BT dersinin öğretim programında teorik, uygulama ve işbirlikli öğrenme şeklinde işlenmesi, ders kapsamında grup ve bireysel uygulama etkinliklerinin yapılması beklenmektedir (TTKB, 2016).

Öğretim programının başarıya ulaşabilmesi için BT öğretmenlerinin ders kapsamında ne gibi etkinlikler gerçekleştirdikleri ve bu etkinliklerin belirlenen öğretim programına ne denli uygun olduğunun önemli bir husus olduğu söylenebilir (Cakir ve Yildirim, 2015). Akbıyık ve Seferoğlu (2012) tarafindan yapılan araştırmada, öğretmenlerin anlatacağı konuyu projeksiyon aracılığı ile anlattıktan sonra öğrencilerden uygulama yapmalarını istemek şeklinde veya öğrencilerin çalışma yaprakları veya ders kitabındaki talimatları dikkate alarak uygulama yapmalarını istemek şeklinde derslerin yürütüldüğü ifade edilmektedir. Kural Er ve Güven (2008) tarafından yapılan çalışma sonuçlarına göre, öğretmenlerin bilgisayar dersinin kazanımlarının teknolojideki gelişim ve değişimlere, bu dersi alan öğrencilerin ilgi, ihtiyaç ve hazır bulunuşluklarına uygun olmadığı fikrinde birlik sağladıkları, bundan dolayı da bilgisayar derslerinde olağan ders programlarından farklı program izledikleri ortaya çıkmıştır. Topu ve Göktaş (2012) tarafından yapılan çalışmada, BT öğretmenleri ile yüz yüze yapılan görüşmelerde öğretmenlerin, öğretim programı dışına çıkıp daha anlaşılır bir şekilde dersi işledikleri, dersin oyun dersi olarak algılandığ 1 ve öğretmenin bir tamirci gibi görüldüğü ifadeleri yer almaktadır. Fırat Durdukoca ve Arıbaş (2011) tarafından yapılan çalışmada ise BT derslerinde yer verilen etkinliklerin soyut olduğu ve görsel materyallerle desteklenmediğini bu durumun öğrencilerin gelişim düzeylerine uygun olmadığı görüşüne varmışlardır. Lee ve Lee (2014) yaptıkları çalışmada, öğretmen adaylarının üniversite eğitimlerinde, hazırladıkları ders 
planlarında müfredata yönelik materyaller tasarlayarak teknoloji entegrasyonu hakkında bilgi sahibi olmalarının önemli bir strateji olabileceğini vurgulamaktadırlar.

Bilgisayar derslerinin etkin olabilmesi için öğretmenlerin programı ne düzeyde uyguladıklarının yanı sıra MEB tarafından hazırlanan programların gelişen teknolojiye göre ne kadar yeterli olduğu, programın gerçekleştirilmesi için okullarda uygun firsatlar olup olmadığı, öğretmenlerin mevcut firsatları etkin kullanıp kullanmadıkları alanyazında sürekli tartışılan konulardır. Derslerde teknolojiyi entegre etmek, zengin bir öğretim ortamı oluşturmada önemli bir rol oynamaktadır (Mishra ve Koehler, 2006). Law ve Plomp (2003), derslerde teknoloji entegrasyonundan sorumlu olan BT öğretmenlerinin rollerinin ülkeden ülkeye değişmesine rağmen, genelde okul müfredatlarına uygun etkinlikler yapıldığını belirtmektedirler. Bununla birlikte, Çengel (2007) tarafından yapılan çalışmada, öğrenme ve öğretme süreçleri ile ilgili olarak, okullardaki bilgisayar laboratuarlarının fiziksel ortamı ve alt yapısının önemli olduğu ve bilgisayar ders kitaplarına ilişkin öğretmenler arasında bir fikir birliği bulunmadığı ortaya çıkmıştır. Gil-Flores, Rodríguez-Santero ve Torres-Gordillo (2017), İspanya'da 192 ortaokulda 3339 öğretmenle yaptıkları çalışmanın sonuçları, eğitim yazılımı, öğretmenlerin BT eğitimi, öğretmenler arasında işbirliği, algılanan öz-yeterlik ve öğretim kavramlarının mevcudiyetinin BT kullanımını etkilediğini göstermektedir. Son zamanlarda yürütülen başka bir araştırmada Tondeur, Aesaert, Prestridge ve Consuegra (2018) BT öğretmenlerinin derste etkinlikleri uygulamada; üniversitede aldıkları eğitimler, BT yeterlikleri, tutumları ve diğer meslektaşları ile olan iletişimleri gibi unsurların etkili olduklarını ifade etmişlerdir. Kabakçı, Kurt ve Yıldırım (2008) tarafından yapılan araştırmada öğretmenlerin öğretim programının kazanım ve değerlendirme aşamaları hakkında olumlu görüşlere sahip oldukları ancak programın içerik kısmı ve öğretme-öğrenme süreçleri hakkında kesin bir görüşe sahip olmadıkları saptanmıştır.

Bilindiği gibi ülkemizde BT dersi öğretim programı 2018 y1lında değişmiş ve 20182019 güz yarıyılından itibaren uygulanmaya başlanmıştır. Ancak bu araştırma program değişikliğinden önce yapılmış ve raporlanmıştır. Bu yüzden eski program esas alınarak gerçekleştirilmiştir. Bu çreçevede araştırma kapsamında BT öğretmenlerinin ders içerisinde öğretim programına ne denli bağlı kaldıklarını, ders öğretim programı ile öğretmenlerin işledikleri dersler arasında farklılaşma olup olmadığı, varsa bu farklılaşmanın nedenini ortaya koymak amaçlanmaktadır.

\section{Problem cümlesi}

Bilişim teknolojileri öğretmenlerinin sınıflarında gerçekleştirdiği etkinlikler, bu etkinliklerin programa uygunluğu ve gerekçeleri nelerdir?

\section{Alt problemler}

1. BT öğretmenleri derslerinde ne tür etkinliklere yer vermektedirler?

2. BT öğretmenlerinin bu etkinlikleri tercih etme gerekçeleri nelerdir?

3. Öğretmenler derslerde yapılan etkinliklerin programa uygunluğu konusunda ne düşünmektedir?

4. BT öğretmenlerinin ders etkinliklerinin programa uygunluğu cinsiyete göre farklılık göstermekte midir?

5. BT öğretmenlerinin ders etkinliklerinin programa uygunluğu mezun olunan fakülte türüne göre farkl1l1k göstermekte midir?

6. BT öğretmenlerinin k1demleri derslerde gerçekleştirilen etkinliklerin programa uygunluğu arasında ilişki var mıdır?

\section{Yöntem}

\section{Araştırma deseni}

$\mathrm{Bu}$ araştırmada tarama modeli kullanılmıştır. Bu kapsamda araştırmada bilişim teknolojileri öğretmenlerinin sınıflarında gerçekleştirdiği etkinlikler, bu etkinliklerin programa uygunluğu ve gerekçeleri taranmaya çalışılmıştır. Büyüköztürk ve diğerlerine (2016) göre tarama modeli, 
bir topluluğun belirli özelliklerini ortaya çıarmak için verilerin toplanmasını amaçlayan çalışmalar olarak tanımlanmaktadır.

\section{Çalışma grubu}

Bu araştırmanın çalışma grubunu Türkiye'nin çeşitli illerinden rastgele seçilmiş 101'i kadın ve 99'u erkek olmak üzere toplam 200 ortaokul bilişim teknolojileri öğretmeni oluşturmaktadır. Öğretmenlerin mezun oldukları bölümlerinin cinsiyete göre dağılımı Tablo1'de verilmiştir.

Tablo 1.

Bölümlerin Cinsiyete Göre Dağılımı

\begin{tabular}{cccccc}
\hline & & Eğitim Fak. & \multicolumn{2}{c}{ Teknik Eğitim Fak. } & \multirow{2}{*}{ Toplam } \\
\cline { 3 - 5 } & & Böte & Bilg. Sist. Eğt. & Elekt. ve Bilg. Eğt. & \\
\hline \multirow{2}{*}{ Cinsiyet } & Erkek & 73 & 22 & 4 & 99 \\
& Kadın & 91 & 9 & 1 & 101 \\
\hline \multicolumn{2}{c}{ Toplam } & 164 & 31 & 5 & 200 \\
\hline
\end{tabular}

Tablo 1'de görüldüğg̈ gibi çalışma grubunda yer alan öğretmenlerin önemli bir kısmı Böte bölümü mezunudur. Teknik eğitim fakültesi mezunlarının genellikle mesleki ve teknik liselerde görev yapıyor olması bu duruma neden olmuş olabilir. Öğretmenlerin kedemlerine göre dağılımlarına bakıldığında 1 yıldır öğretmenlik yapanların oranı \%24,5 iken 2 ile 10 yıl arasında görev süresi olanların oranı yaklaşı \% 10 civarında değişmektedir. 10 yıldan fazla süre ile görev yapanların oranı ise yaklaşık \%3 civarında değişmektedir. Bu verilere göre çalışma grubun oluşturanların büyük çoğunluğu göreve yeni başlamış öğretmenlerden oluşmaktadır. Tablo 3'de öğrenmelerin görev yaptığı yerleşim birimi türüne göre dağılımları özetlenmiştir.

Tablo 2.

Öğretmenlerin Görev Yaptıkları Yerleşim Birimleri

\begin{tabular}{lcc}
\hline \multicolumn{1}{c}{ Yerleşim Birimi } & $\mathrm{f}$ & $\%$ \\
\hline Köy & 36 & 18,0 \\
Kasaba & 13 & 6,5 \\
İlçe & 70 & 35,0 \\
İl & 81 & 40,5 \\
\hline Toplam & 200 & 100,0 \\
\hline
\end{tabular}

Tablo 2'ye göre köyde görev yapan öğretmenlerin oranı \%18, kasabada görev yapan öğretmenlerin oran $\% 6,5$, İlçe merkezinde görev yapan öğretmenlerin oranı $\% 35$ ve İl merkezinde görev yapan öğretmenlerin oranı ise $\% 40,5$ 'dır. Bu verilere göre öğretmenlerin büyük çoğunluğu il ve ilçe merkezlerinde görev yapmaktadırlar.

\section{Veri toplama araçları}

Çalışmada veri toplama aracı olarak "Bilișim Teknolojileri Öğretmenlerinin Ders İşleyiş Süreçleri” anketi kullanılmıştır. Bu anket BT öğretmenlerinin bilişim teknolojileri derslerinde gerçekleştirdikleri etkinlikleri ve Bilişim Teknolojileri dersi programına dönük görüşlerini belirlemek için hazırlanmıştır. Anketin hazırlanma aşamasında BT öğretmenlerine 10 adet açık uçlu soru sorulmuştur. $\mathrm{Bu}$ soruların oluşturulmasında alan uzmanlarından görüş alınmış, uzmanların görüşleri doğrultusunda sorulara son şekli verilmiştir. Bu sorulara 20 BT öğretmeni cevap vermiş ve elde edilen görüşler madde haline dönüş̧ürülmüştür. Bu sorulara verilen ortak cevaplar Tablo 3'de özetlenmiştir. Bu cevaplardan yola çıkarak 24 maddelik beşli likert tipi anket formu oluşturulmuştur. Anketin iç tutarlılık katsayısı Cronbach's alpha 0,723 olarak bulunmuştur. 
Tablo 3.

Anket Hazırlama Soruları

\begin{tabular}{|c|c|c|}
\hline Açık Uçlu Sorular & Verilen Ortak Cevaplar & $\begin{array}{l}\text { Öğretmen } \\
\text { Sayıs1 }\end{array}$ \\
\hline \multirow{8}{*}{$\begin{array}{l}\text { Dersinizde genellikle ne } \\
\text { tür etkinliklere yer } \\
\text { veriyorsunuz? }\end{array}$} & Teori & 2 \\
\hline & Uygulama & 10 \\
\hline & İstasyon Tekniği (Labsı) & 4 \\
\hline & Konu anlatımı & 2 \\
\hline & Gösterip yaptırma & 2 \\
\hline & Kisa filmler & 1 \\
\hline & Kod yazma etkinlikleri & 3 \\
\hline & $3 \mathrm{~d}$ çizim & 1 \\
\hline \multirow{11}{*}{$\begin{array}{l}\text { Derslerde hangi konulara } \\
\text { ağırlık veriyorsunuz? }\end{array}$} & Office programları & 5 \\
\hline & BİT konusu,( Labsız) & 5 \\
\hline & Siber suçlar, (Labsız) & 2 \\
\hline & Klavye yazım eğitimi & 3 \\
\hline & Bilișim teknolojileri donanım ve güvenlik yazılımları & 4 \\
\hline & Temel bilgisayar kullanma becerileri & 4 \\
\hline & İnternet güvenlik & 4 \\
\hline & $\begin{array}{l}\text { Sosyal ağlarda ve internette bilgi güvenliklerini } \\
\text { sağlayabilecekleri konular }\end{array}$ & 2 \\
\hline & Algoritma ve programlama mantı̆̆ & 4 \\
\hline & Scratch eğitimi & 3 \\
\hline & Sosyal medya & 2 \\
\hline \multirow{4}{*}{$\begin{array}{l}\text { Öğrencilere işlenen } \\
\text { konularla ilgili uygulama } \\
\text { yaptırıyor musunuz? }\end{array}$} & Evet & 14 \\
\hline & Şu an uygun ortam olmadığından yaptıramıyorum. & 2 \\
\hline & $\begin{array}{l}\text { Dersimin en az yarısını uygulama süresi için kullanıyorum } \\
\text { çünkü kendileri yapmadan ögrenmede kalıcıllk sağlayamayız } \\
\text { kanaatindevim }\end{array}$ & 2 \\
\hline & Kesinlikle & 3 \\
\hline \multirow{3}{*}{$\begin{array}{l}\text { Öğrenciler derse karşı ilgi } \\
\text { gösteriyorlar mı? }\end{array}$} & Uygulamalı derslere daha istekliler & 3 \\
\hline & $\begin{array}{l}\text { Oldukça ilgililer en sevdikleri ders bilişim teknolojileri ve } \\
\text { yazılım dersi }\end{array}$ & 16 \\
\hline & Hayır & 1 \\
\hline \multirow{6}{*}{$\begin{array}{l}\text { Öğretim programı sizce } \\
\text { uygun mu? }\end{array}$} & Hayır & 8 \\
\hline & $\begin{array}{l}\text { Öğretim programı uygun da maalesef öğretim programına } \\
\text { uygun altyapı yok }\end{array}$ & 2 \\
\hline & Daha ileri seviye bir öğretim programı olabilir & 3 \\
\hline & Kodlamaya ağırlık verilebilir & 1 \\
\hline & Yetersiz & 3 \\
\hline & Evet & 3 \\
\hline \multirow{5}{*}{$\begin{array}{l}\text { Derslerde öğrencilere oyun } \\
\text { oynama firsatı veriyor } \\
\text { musunuz? }\end{array}$} & Hayır & 7 \\
\hline & Evet, motive ediyor & 5 \\
\hline & Konuya bağlı kalınacak şekilde eğitsel oyunlar oynatıyorum & 3 \\
\hline & $\begin{array}{l}\text { Eğer önceki bütün haftalarda işlediğim konularla ilgili } \\
\text { sorduğum sorulara sınıfın } \% 80 \text { doğru cevap verirse } \\
\text { oynayabilirler }\end{array}$ & 1 \\
\hline & Scratch üzerinden hem öğrenip hem de oynayabiliyorlar & 3 \\
\hline \multirow{3}{*}{$\begin{array}{l}\text { Dersleri kazanımlara } \\
\text { uygun işliyor musunuz? }\end{array}$} & Evet & 15 \\
\hline & Hayır & 2 \\
\hline & Kazanımlar bulunduğumuz çağa uygun değil & 3 \\
\hline \multirow{4}{*}{$\begin{array}{l}\text { Dersin yapılması için } \\
\text { gerekli araç gereçler } \\
\text { mevcut mu? }\end{array}$} & Evet & 6 \\
\hline & Hayır & 6 \\
\hline & Kismen & 6 \\
\hline & $\begin{array}{l}\text { Bazı öğrenciler bir bilgisayarda iki kişi oturmak zorunda. } \\
\text { Açıç̧ası akıllı tahtalarla dolu okula } 20 \text { bilgisayar }\end{array}$ & 2 \\
\hline
\end{tabular}


önemsenmediğini gösteriyor

\begin{tabular}{llc}
\hline & Hayır & 7 \\
& Evet & 4 \\
& Bazıları öğrenci seviyesinin altında kalıyor fakat uygun araç- & 1 \\
Programda bulunan & gereç olmadığından bu şekilde işlemek zorundayım. & \\
kazanımlar öğrenci & Yetersiz & 2 \\
seviyesine uygun mu? & Program güncel değil ve programın içerisinde gerekli & 1 \\
& konularda kazanımlar eksik öğrenciler için 1.basamak & \\
& 5.basamak çok basit ve gereksiz pek çok kazanım içeriyor & \\
& acilen güncelleme ve eklemeler gerekli & 12 \\
& Evet & 1 \\
& Buluş ve Araştırmaya dayalı yaklaşımlara ağılık vererek & \\
Dersinizde alternative & öğrencilerin sıkılmamasını ve aktif olmasını sağlamaya & \\
öğretim yaklaşımları & Çalısıorum & 2 \\
kullanıyor musunuz? & Örencileri daha çok aktif tutmaya çalışıyorum & 1 \\
& Mutlaka. Sınıflar kalabalık olduğu için dikkatleri çok & \\
& dağıllıor & 2 \\
& Bazen & 2 \\
\hline
\end{tabular}

\section{Veri toplama süreci}

Araştırmanın verileri internet üzerinden toplanmış ve bu süreç 1 ay sürmüştür. Bir öğretmenin anketi cevaplama süresi ortalama 10 dakika sürmektedir. Verilerin samimi ve doğru olarak girildiği varsayılmıştır.

\section{Veri analizi}

Araştırmada elde edilen verilerin analizi SPSS 20 paket programı aracılığı ile yapılmıştır. Verilerin analizinde; ortalama, frekans ve standart sapma hesaplama, pearson korelasyon, bağımsız örneklem t testi ve anova analizleri kullanılmıştır.

\section{Bulgular}

BT öğretmenlerinin derslerinde yer verdiği eğitsel etkinliklere ilişkin görüşleri tablo 4'te özetlenmiştir.

Tablo 4.

Öğretmen Görüşleri

\begin{tabular}{llcc}
\hline & & $\bar{X}$ & $\mathrm{~S}$ \\
\hline & Gösterip yaptırma yöntemine yer veriyorum & 4,09 & 1,12 \\
& Derste kısa filmlerden yararlanıyorum & 3,67 & 1,10 \\
Dersinizde & Dersi bilgisayarda işleyerek yürütüyorum & 3,61 & 1,17 \\
genellikle ne tür & Derste kod yazma etkinliklerine yer veriyorum & 2,98 & 1,29 \\
etkinliklere yer & Derslerde öğrencilerin sadece eğitsel oyunları oynamalarına firsat & 2,82 & 1,11 \\
veriyorsunuz? & veriyorum. & 2,48 & 1,01 \\
& İstasyon Tekniğine yer veriyorum & 2,43 & 1,09 \\
& Dersi tamamen teorik olarak işliyorum & 2,43 & 1,25 \\
& Derslerde öğrencilerin oyun oynamalarına firsat veriyorum. & 1,89 & 1,06 \\
\hline & Derste 3d çizim etkinliklerine yer veriyorum. & 4,09 &, 78 \\
& Derste ağırlıklı olarak bilişim teknolojileri konusuna yer veriyorum. & 3,81 & 1,01 \\
& Derste ağırlıklı olarak temel bilgisayar kullanma becerilerine yer & 3,70 & 1,03 \\
Derslerde hangi & veriyorum. & 3,64 &, 90 \\
konulara ağırlık & Derste ağırlıklı olarak Office programlarına yer veriyorum. & 3,50 &, 97 \\
veriyorsunuz? & Derste ağırlıklı olarak donanım konusuna yer veriyorum. & 3,40 & 1,00
\end{tabular}


Derste ağırlıklı olarak klavye becerileri yer veriyorum.

Derste ağırlıklı olarak Algoritma ve programlama konularına yer

\begin{tabular}{llrr} 
& Derste ağırlıklı olarak Scracth'a yer veriyorum. & 2,51 & 1,32 \\
\hline Araç Gereç & Dersin yapılması için gerekli araç gereçler mevcuttur. & 2,58 & 1,20 \\
\hline İlgi & Öğrenciler derse karşı ilgi gösteriyorlar. & 3,87 &, 86 \\
\hline \multirow{3}{*}{ Öğretim programı } & Dersleri kazanımlara uygun bir şekilde işliyorum. & 3,68 &, 96 \\
& Kazanımlar bulunduğumuz çağa uygun değil. & 3,34 & 1,03 \\
& Programda bulunan kazanımlar öğrenci seviyesine uygundur. & 3,14 &, 91 \\
& Öğretim programı bence yeterlidir. & 2,15 &, 94 \\
\hline
\end{tabular}
$* \mathrm{~N}=200$

\section{Bilişim Teknolojileri öğretmenleri ne tür etkinliklere yer veriyorlar?}

Tablo 4 incelendiğinde BT öğretmenlerinin derslerinde ağırlıklı olarak gösterip yaptırma $(\bar{X}=4,9)$, kısa filmlerden yararlanma $(\bar{X}=3,67)$, dersin bilgisayarda işleyerek yürütülmesi $(\bar{X}=3,61)$, kod yazdırma $(\bar{X}=2,98)$ ve eğitsel oyun $(\bar{X}=2,82)$ etkinliklerine yer verdikleri görülmektedir. İstasyon tekniği $(\bar{X}=2,48)$, teorik ders anlatımı $(\bar{X}=2,43)$ ve serbest oyun etkinliklerine $(\bar{X}=2,43)$ daha az yer verildiği, $3 \mathrm{~d}$ çizime ise nadiren yer verildiği $(\bar{X}=1,89)$ görülmektedir. Bilişim teknolojileri ve Yazılım Dersi öğretim programı incelendiğinde öğrencilerin temel yetkinlikleri kazanabilmeleri için teorinin yanında uygulamaya çokça zaman ayrılması gerektiği, işbirlikli öğrenme ve proje tabanlı öğrenme etkinliklerinin işe koşulması gerektiği ve teknik alt yapı eksiği bulunan okullarda öğrencilerin bilgisayar olmadan öğrenebilmeleri için farklı etkinliklerin ve uygulamaların yapılmasının önemli olduğu vurgulanmaktadır (TTBK, 2018). Bu çerçevede değerlendirildiğinde öğretmenlerin alt yapısı olan okullarda bilgisayar başında uygulama yapmalarına firsat verdikleri, gösterip yaptırma, dersi bilgisayar başında eğitim, kod yazdırma gibi bireysel etkinliklere yer verdikleri, ancak öğretim programında önerilen proje tabanlı ve işbirlikli öğrenme yöntemlerine ilişkin etkinliklere yeterince yer vermedikleri söylenebilir. Oysaki öğretim programında öğrencilerin öğrenme sürecinde iş birlikli çalışma becerileri edinmeleri, sosyal ortamlardan faydalanmaları ve öğrendiklerini paylaşmaları hususunda özel bir amaç belirtilmektedir (TTKB, 2018).

Tablo 4'de öğretmenlerin derslerinde yer verdikleri konular incelendiğinde en çok bilişim teknolojileri $(\bar{X}=4,09)$, temel bilgisayar kullanım becerileri $(\bar{X}=3,81)$, Office uygulamaları $(\bar{X}=3,70)$, güvenlik konuları $(\bar{X}=3,50)$ ve klavye berilerine $(\bar{X}=3,30)$ ilişkin konulara yer verildiği; algoritma ve programlama $(\bar{X}=2,89)$ ile Scracth ortamında programlama $(\bar{X}=2,51)$ konularına daha az yer verildiği görülmektedir. Öğretim programı incelendiğinde ise hem 5 hem de 6. Sinıfta bilişim teknolojilerine 6 saat, etik ve güvenliğe 8 saat, iletişim, araştırma ve iş birliğine 8 saat, görsel işleme, kelime işlemci ve sunu programlarına 14 saat yer ayrılmışken, problem çözme ve programlamaya 36 saat ayrılmakta, bu süre tüm programın \%50'sine karş1lık gelmektedir (TTKB, 2018). Bu çerçevede incelendiğinde öğretmenlerin siniflarında programlamaya daha fazla yer vermeleri gerekirken, en az yer verdikleri konu programlama olduğu söylenebilir. Programda bilişim teknolojilerine 6 saat yer ayrılmışken, öğretmenlerin bu konuyu daha çok ele aldıkları söylenebilir. Öğretim programı, programlama konusu ile öğrencilerin teknik birikime sahip olmalarını ve programlama dillerinden en az birini bilmeleri konusunda bir amaç belirlemiştir. Bunun yanı sıra problem çözme becerilerinin gelişimi için de programlama eğitiminin önemi vurgulanmaktadır (TTKB, 2018).

\section{Öğretmenlerin etkinliklere yer verme gerekçeleri nelerdir?}

Öğretmenlerin çoğunluğu $(\bar{X}=3,68)$ bu etkinliklere kazanımlara uygun oldukları gerekçesiyle yer verdiklerini ifade etmektedirler. Öğretmenlerin dersin yapılması için gerekli araç gereçlerin mevcut olduğuna ilişkin görüş ortalamaları $(\bar{X}=2,58)$ 'dir. Buna göre gerekli araç gereçlerin tüm okullarda mevcut olmadığı söylenebilir. $\mathrm{Bu}$ çerçevede sınıflarında gerekli araç gereç 
bulunmamasından dolayı öğretmenlerin araç gereç gerektiren etkinliklere yer veremedikleri söylenebilir. $\mathrm{Bu}$ sonuçlardan da görüldüğü üzere öğretmenlerin elindeki imkânların, kazanımları ve farklı etkinlikleri gerçekleştirme durumları üzerinde etkisinin önemini ortaya koymaktadır. Kazanımların uygunluğunun yanı sıra laboratuvar veya sınıf ortamının yeterli donanıma sahip oluşunun dersin işleniş aşamasında büyük bir önemi olduğu söylenebilir. Öğretim programı incelendiğinde teknik alt yap1 eksiği bulunan okullarda öğrenciler için zengin öğrenme ortamları oluşturulması önerilmekte bu kapsamda öğrencilerin farklı donanım ve yazılım seçenekleri ile tanıştırılması amaçlanmaktadır. Öğretim programı aynı zamanda teknik altyapı ve bilgi açısından seçenekler sunmakta ve tercihe ağlı olarak etkinliklerin uygulanabilmesini sağlamaktadır (TTKB, 2018).

\section{Yapılan etkinlikler programa uygun mudur?}

Tablo 4'te öğretmenlerin genellikle $(\bar{X}=3,87)$ dersleri kazanımlara uygun şekilde işlediklerini ve kazanımların öğrencilerin seviyelerine uygun olduğunu $(\bar{X}=3,14)$ ifade etmektedirler. Öte yandan öğretim programının yeterliliğine ilişkin ortalamanın $(\bar{X}=2,15)$, kazanımların çağa uygun olmadığına ilişkin ortalamanın ise $(\bar{X}=3,34)$ olduğu görülmektedir Buna göre öğretmenlerin ders uygulamalarında programa uygun davrandıklarına, kazanımların öğrenci düzeyine uygun olduğuna, ancak kazanımların çağın gerekleri için yeterli olmadığına ve yeterli olmadığına inandıkları söylenebilir. Tablo 5 'de öğretmen görüşleri İle kıdem arasında bir ilişki olup olmadığına ilişkin sonuçlar özetlenmiştir.

Tablo 5.

Öğretmenlerin Kıdemleri ve Görüşleri Arasındaki Korelasyon Tablosu

\begin{tabular}{|c|c|c|}
\hline & & Kidem \\
\hline \multirow{9}{*}{$\begin{array}{l}\text { Dersinizde } \\
\text { genellikle ne tür } \\
\text { etkinliklere yer } \\
\text { veriyorsunuz? }\end{array}$} & Gösterip yaptırma yöntemine yer veriyorum. & R:,086 P:,225 \\
\hline & Derste kısa filmlerden yararlanıyorum. & R:-,151 P:,033 \\
\hline & Dersi bilgisayarda işleyerek yürütüyorum. & $\mathrm{R}:, 182 \mathrm{P}:, 010$ \\
\hline & Derste kod yazma etkinliklerine yer veriyorum. & R:,060 P:,395 \\
\hline & $\begin{array}{l}\text { Derslerde öğrencilerin sadece eğitsel oyunları oynamalarına firsat } \\
\text { veriyorum. }\end{array}$ & R:-,047 P:,509 \\
\hline & İstasyon Tekniğine yer veriyorum. & R:,183 P:,010 \\
\hline & Dersi tamamen teorik olarak işliyorum. & R:-,143 P:,043 \\
\hline & Derslerde öğrencilerin oyun oynamalarına firsat veriyorum. & R:,031 P:,662 \\
\hline & Derste $3 \mathrm{~d}$ çizim etkinliklerine yer veriyorum. & $\mathrm{R}:-, 052 \mathrm{P}:, 463$ \\
\hline \multirow{9}{*}{$\begin{array}{l}\text { Derslerde hangi } \\
\text { konulara ağırlık } \\
\text { veriyorsunuz? }\end{array}$} & Derste ağırlıklı olarak bilişim teknolojileri konusuna yer veriyorum. & R:-,145 P:,041 \\
\hline & $\begin{array}{l}\text { Derste ağırlıklı olarak temel bilgisayar kullanma becerilerine yer } \\
\text { veriyorum. }\end{array}$ & R:-,099 P:,162 \\
\hline & Derste ağırlıklı olarak Office programlarına yer veriyorum. & R:-,058 P:,415 \\
\hline & Derste ağırlıklı olarak donanım konusuna yer veriyorum. & R:-,250 P: ,000 \\
\hline & Derste ağırlıklı olarak siber suçlar konusuna yer veriyorum. & R: -,103 P:,146 \\
\hline & $\begin{array}{l}\text { Derste ağırlıklı olarak güvenlik ve güvenlik yazılımları konusuna } \\
\text { yer veriyorum. }\end{array}$ & R:-,185 P:,009 \\
\hline & Derste ağırlıklı olarak klavye becerileri yer veriyorum. & R:-,132 P:,063 \\
\hline & $\begin{array}{l}\text { Derste ağırlıklı olarak Algoritma ve programlama konularına yer } \\
\text { veriyorum. }\end{array}$ & R:,030 P:,669 \\
\hline & Derste ağırlıklı olarak Scracth'a yer veriyorum. & R:-,004 P: ,960 \\
\hline Araç Gereç & Dersin yap1lması için gerekli araç gereçler mevcuttur. & R:,205 P:,004 \\
\hline İlgi & Öğrenciler derse karş1 ilgi gösteriyorlar. & R:,034 P:,631 \\
\hline \multirow{4}{*}{$\begin{array}{l}\text { Öğretim } \\
\text { programı }\end{array}$} & Dersleri kazanımlara uygun bir şekilde işliyorum. & R:,129 P:,068 \\
\hline & Kazanımlar bulunduğumuz çağa uygun değil. & R: -,006 P:,938 \\
\hline & Programda bulunan kazanımlar öğrenci seviyesine uygundur. & $\mathrm{R}:, 016 \mathrm{P}:, 826$ \\
\hline & Öğretim programı bence yeterlidir. & R: ,090 P:,206 \\
\hline
\end{tabular}

$* \mathrm{~N}=200$ 
Öğretmenlerin görev sürelerinin artmasıyla derslere ilişkin görüşlerinin arasında ilişki olup olmadığını belirlemek için parametrik testlerden pearson korelasyon testi yapılmıştır. Test sonuçlarına göre; öğretmenlerin derste $3 \mathrm{~d}$ çizim etkinliklerine, office programlarına, siber suçlar konusuna, klavye becerilerine, temel bilgisayar kullanma becerilerine, Scratch'e ve eğitsel oyun oynamalarına yer vermeleri ve kazanımların bulunduğumuz çağa uygun olmadığını düşünmeleri görev süreleri ile negatif yönde bir ilişki içerisindedir ancak bu ilişki istatistiksel olarak anlamlı değildir $(\mathrm{R}=-0,052,-0,058,-0,103,-0,132,-0,099,-0,004,-0,047,-0,006 ; \mathrm{p}>0,05)$. Bu durum öğretmenlerin görev süreleri arttıkça yukarıda verilen etkinliklerin farklılaşmadığı anlamına gelmektedir.

Öğretmenlerin, derste kod yazma etkinliklerine, gösterip yaptırma yöntemine, algoritma ve programlama konularına ve derste oyun oynamalarına yer vermeleri ve dersi kazanımlara uygun şekilde işlemeleri, öğrencilerin derse ilgi göstermeleri, kazanımları öğrenci seviyesine uygun bulmaları ve öğretim programının yeterli olduğunu düşünmeleri görev süreleri ile pozitif yönde bir ilişki olmasına rağmen bu ilişki anlamlı bulunmamıştır $(\mathrm{R}=0,060,0,086,0,030,0,031$, $0,129,0,034,0,016,0,090 ; p>0,05)$. Bu durum öğretmenlerin görev süreleri arttıkça yukarıda verilen etkinliklere yer vermelerinin ve görüşlerinin farklılaşmadığı anlamına gelmektedir.

Öğretmenlerin, dersi teorik olarak işlemeleri, kısa filmden yaralanmaları, bilişim teknolojileri, donanım ve güvenlik ve güvenlik yazılımları konularına yer vermeleri ile görev süreleri arasında negatif yönde anlamlı bir ilişki bulunmaktadır $(\mathrm{R}=-0,143,-0,151,-0,145$, $0,250,-0,185 ; \mathrm{p}<0,05)$. Buna göre öğretmenlerin görev süreleri arttıkça bu etkinlik ve konulara yer verme düzeylerinin azaldığı, bir başka ifadeyle göreve yeni başlayan öğretmenlerin bu konulara ve etkinliklere daha çok yer verdikleri söylenebilir.

Öğretmenlerin, dersi bilgisayarda işleyerek yürütmeleri, istasyon tekniğine yer vermeleri ve dersin yapılması için gerekli araç gereçlerin mevcut olma durumları ile görev süreleri arasında pozitif yönde anlamlı bir ilişki bulunmaktadır $(R=0,182,0,183,0,205 ; \mathrm{p}<0,05)$. $\mathrm{Bu}$ durum öğretmenlerin görev süreleri arttıkça yukarıdaki etkinliklere yer vermelerinin ve kullanılacak araç gereçlerin mevcut olma durumunun farklılaşmadığı anlamına gelmektedir.

Tablo 6.

Öğretmenlerin Görüşlerinin Cinsiyete Göre Fark1

\begin{tabular}{|c|c|c|c|c|c|c|c|}
\hline & & Cinsiyet & $\overline{\mathrm{X}}$ & $\mathrm{S}$ & sd & $\mathrm{t}$ & $\mathrm{P}$ \\
\hline \multirow{18}{*}{$\begin{array}{l}\text { Dersinizde } \\
\text { genellikle ne tür } \\
\text { etkinliklere yer } \\
\text { veriyorsunuz? }\end{array}$} & \multirow{2}{*}{ Gösterip Yaptırma Yöntemi } & Erkek & 4,2 & 1,04 & 198 & ,826 & ,410 \\
\hline & & Kadın & 4,0 & 1,20 & & & \\
\hline & \multirow{2}{*}{ Kisa Filmlerden Yararlanma } & Erkek & 3,5 & 1,10 & 198 & $-2,579$ & 011 \\
\hline & & Kadın & 3,9 & 1,06 & & & \\
\hline & \multirow{2}{*}{ Dersin Bilgisayarda İşlenmesi } & Erkek & 3,6 & 1,13 & 198 &,- 589 & ,557 \\
\hline & & Kadın & 3,7 & 1,21 & & & \\
\hline & \multirow{2}{*}{ Kod Yazma Etkinlikleri } & Erkek & 2,9 & 1,31 & 198 &,- 545 & ,586 \\
\hline & & Kadın & 3,0 & 1,29 & & & \\
\hline & \multirow{2}{*}{ Eğitsel Oyun Oynama } & Erkek & 2,9 & 1,00 & 198 & 1,633 &, 104 \\
\hline & & Kadın & 2,7 & 1,20 & & & \\
\hline & \multirow{2}{*}{$\begin{array}{l}\text { İstasyon Tekniğine Yer } \\
\text { Verilmesi }\end{array}$} & Erkek & 2,4 & 0,97 & 198 & $-1,120$ & 264 \\
\hline & & Kadın & 2,6 & 1,04 & & & \\
\hline & \multirow{2}{*}{ Dersin Teorik İşlenmesi } & Erkek & 2,5 & 1,04 & 198 & ,573 & ,567 \\
\hline & & Kadın & 2,4 & 1,13 & & & \\
\hline & \multirow{2}{*}{ Oyun oynama } & Erkek & 2,7 & 1,25 & 198 & 3,052 & ,003 \\
\hline & & Kadın & 2,2 & 1,19 & & & \\
\hline & \multirow{2}{*}{ 3d Çizim Etkinlikleri } & Erkek & 1,9 & 1,03 & 198 & ,318 & ,751 \\
\hline & & Kadın & 1,8 & 1,09 & & & \\
\hline \multirow{5}{*}{$\begin{array}{l}\text { Derslerde hangi } \\
\text { konulara ağırlık } \\
\text { veriyorsunuz? }\end{array}$} & \multirow{2}{*}{ Bilişim Teknolojileri Konusu } & Erkek & 4,1 & 0,79 & 198 &,- 073 & ,942 \\
\hline & & Kadın & 4,2 & 0,76 & & & \\
\hline & Bilgisayar Kullanma & Erkek & 3,7 & 1,00 & 198 &,- 719 & ,473 \\
\hline & Becerileri & Kadın & 3,9 & 1,03 & & & \\
\hline & Office Programları & Erkek & 3,6 & 0,99 & 198 & $-1,208$ & ,229 \\
\hline
\end{tabular}


Bilişim Teknolojileri Öğretmenlerinin Derslerşinde Gerçekleştirdiği Etkinlikler, Bu Etkinliklerin Programa Uygunluğu ve Gerekçeleri

\begin{tabular}{|c|c|c|c|c|c|c|c|}
\hline & & Kadın & 3,8 & 1,06 & & & \\
\hline & Donanum Konucut & Erkek & 3,6 & 0,81 & 198 &,- 447 & ,655 \\
\hline & Donamm Nonusu & Kadın & 3,7 & 0,98 & & & \\
\hline & Siber Suclar Konusu & Erkek & 3,2 & 0,92 & 198 & $-4,919$ & ,000 \\
\hline & 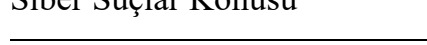 & Kadın & 3,8 & 0,90 & & & \\
\hline & Güvenlik ve Güvenlik & Erkek & 3,2 & 1,03 & 198 & $-2,282$ & ,024 \\
\hline & Yazılımları Konusu & Kadın & 3,6 & 0,96 & & & \\
\hline & & Erkek & 3,2 & 1,09 & 198 & $-1,421$ & ,157 \\
\hline & Aravye Decenten & Kadın & 3,4 & 1,13 & & & \\
\hline & Algoritma ve Programlama & Erkek & 2,9 & 1,24 & 198 & 635 & ,526 \\
\hline & Konuları & Kadın & 2,8 & 1,15 & & & \\
\hline & Scracth Konusu & Erkek & 2,5 & 1,37 & 198 &,- 531 & ,596 \\
\hline & Scractn Konusu & Kadın & 2,6 & 1,28 & & & \\
\hline Arac Gerec & & Erkek & 2,7 & 1,16 & 198 & 1,011 & 313 \\
\hline Araç Uereç & Araç Uereçrermn Mievcuulugu & Kadın & 2,5 & 1,23 & & & \\
\hline İloj & Öğrencilerin Derse İlgisi & Erkek & 3,8 & 0,76 & 198 &,- 266 & ,791 \\
\hline & & Kadın & 3,9 & 0,94 & & & \\
\hline & Derslerin Kazanımlara & Erkek & 3,6 & 0,93 & 198 & $-1,44$ & 151 \\
\hline & Uygunluğu & Kadın & 3,8 & 0,98 & & & \\
\hline & Kazanımların Bulunduğumuz & Erkek & 3,4 & 0,98 & 198 & 1,493 & 137 \\
\hline Öğretim programı & Çağa Uygunluğu & Kadın & 3,2 & 1,06 & & & \\
\hline 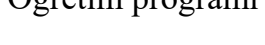 & Kazanımların Öğrenci & Erkek & 3,1 & 0,84 & 198 &,- 907 & ,366 \\
\hline & Seviyesine Uygunluğu & Kadın & 3,2 & 0,98 & & & \\
\hline & Öğretim programının & Erkek & 2,1 & 0,89 & 198 &,- 202 & 840 \\
\hline & Yeterliliği & Kadın & 2,2 & 0,99 & & & \\
\hline
\end{tabular}

*N (Kadın=101, Erkek=99)

Ders etkinliklerinin öğretmenlerin cinsiyetleri arasında farklılık gösterip göstermediğini anlamak için bağımsız örneklem $\mathrm{t}$ testi yapılmıştır. Analiz sonuçlarına göre erkek öğretmenler $(\bar{X}=2,5)$ kadın ögretmenlere $(\bar{X}=2,4)$ göre dersi daha çok teorik olarak işlemektedirler ancak fark anlamlı değildir. $\left(\mathrm{t}_{(198)}=0,573 ; \mathrm{p}>0,05\right)$. Kadın öğretmenler $(\bar{X}=3,7)$ erkek öğretmenlere $(\bar{X}=3,6)$ göre dersi daha çok bilgisayarda işlemektedirler ancak fark anlamlı değildir $\left(t_{(198)}=-\right.$ $0,589 ; \mathrm{p}>0,05)$. Kadın öğretmenler $(\bar{X}=2,6)$ erkek öğretmenlere $(\bar{X}=2,4)$ göre istasyon tekniğine daha çok yer vermektedirler ancak fark anlamlı değildir $\left(t_{(198)}=-1,120 ; p>0,05\right)$. Erkek öğretmenler $(\bar{X}=4,2)$ kadın öğretmenlere $(\bar{X}=4,0)$ göre gösterip yaptırma yöntemine daha fazla yer vermektedirler ancak fark anlamlı değildir $\left(\mathrm{t}_{(198)}=0,826 ; \mathrm{p}>0,05\right)$. Kadın öğretmenler $(\bar{X}=$ $3,0)$ erkek öğretmenlere $(\bar{X}=2,9)$ göre kod yazma etkinliklerine daha çok yer vermektedirler ancak fark anlamlı değildir $\left(\mathrm{t}_{(198)}=-0,545 ; \mathrm{p}>0,05\right)$. Erkek öğretmenler $(\bar{X}=1,9)$ kadın öğretmenlere $(\bar{X}=1,8)$ göre $3 \mathrm{~d}$ çizim etkinliklerine daha çok yer vermektedir ancak aradaki bu fark anlamlı değildir $\left(\mathrm{t}_{(198)}=0,318 ; \mathrm{p}>0,05\right)$. Kadın öğretmenler $(\bar{X}=3,6)$ erkek öğretmenlere $(\bar{X}=$ $3,8)$ göre office programlarına daha çok yer vermektedirler ancak bu fark anlamlı değildir $\left(\mathrm{t}_{(198)}=-1,208 ; \mathrm{p}>0,05\right)$. Kadın öğretmenler $(\bar{X}=3,2)$ erkek öğretmenlere $(\bar{X}=3,4)$ göre klavye becerileri eğitimine daha çok yer vermektedirler ancak fark anlamlı değildir $\left(t_{(198)}=-1,421\right.$; p $>0,05)$. Kadın öğretmenler $(\bar{X}=4,2)$ erkek öğretmenlere $(\bar{X}=4,1)$ göre bilişim teknolojileri konusuna daha çok yer vermektedirler ancak fark anlamlı değildir $\left(t_{(198)}=-0,073 ; p>0,05\right)$. Kadın öğretmenler $(\bar{X}=3,7)$ erkek öğretmenlere $(\bar{X}=3,6)$ göre donanım konusuna daha çok yer vermektedirler ancak fark anlamlı değildir $\left(\mathrm{t}_{(198)}=-0,447 ; \mathrm{p}>0,05\right)$. Kadın öğretmenler $(\bar{X}=3,9)$ erkek öğretmenlere $(\bar{X}=3,7)$ göre bilgisayar kullanma becerileri eğitimine daha fazla yer vermektedirler ancak aralarındaki fark anlamlı değildir $\left(\mathrm{t}_{(198)}=-0,719 ; \mathrm{p}>0,05\right)$. Erkek öğretmenler $(\bar{X}=2,9)$ kadın öğretmenlere $(\bar{X}=2,8)$ göre algoritma ve programlama konularına daha çok yer vermektedirler ancak aralarındaki fark anlamlı değildir $\left(t_{(198)}=0,635 ; p>0,05\right)$. 
Kadın öğretmenler $(\bar{X}=2,6)$ erkek öğretmenlere $(\bar{X}=2,5)$ göre scracth konusuna daha çok yer vermektedirler ancak aralarındaki fark anlamlı değildir $\left(\mathrm{t}_{(198)}=-0,531 ; \mathrm{p}>0,05\right)$. Erkek öğretmenler $(\bar{X}=2,9)$ kadın öğretmenlere $(\bar{X}=2,7)$ göre öğrencilerin sadece eğitsel oyun oynamalarına daha çok yer vermektedirler ancak aradaki bu fark anlamlı değildir $\left(\mathrm{t}_{(198)}=1,633\right.$; $\mathrm{p}>0,05)$. Kadın öğretmenler $(\bar{X}=3,8)$ erkek öğretmenlere $(\bar{X}=3,6)$ göre etkinlikleri daha çok programa uygun olarak yapmaktadırlar ancak fark anlamlı değildir $\left(\mathrm{t}_{(198)}=-1,44 ; \mathrm{p}>0,05\right)$. Erkek öğretmenler $(\bar{X}=3,4)$ kadın öğretmenlere $(\bar{X}=3,2)$ göre kazanımların bulunduğumuz çağa uygun olduğunu daha çok ileri sürmektedirler ancak aradaki bu fark anlamlı değildir $\left(\mathrm{t}_{(198)}=1,493 ; \mathrm{p}>0,05\right)$. Erkek öğretmenler $(\bar{X}=2,7)$ kadın öğretmenlere $(\bar{X}=2,5)$ göre sinıflarında gerekli araç gereçleri yeterli bulmaktadırlar ancak aradaki bu fark anlamlı değildir $\left(\mathrm{t}_{(198)}=1,011\right.$; p>0,05). Kadın öğretmenlerin sınıfındaki öğrencilerin derse karşı olan ilgileri $(\bar{X}=3,9)$ erkek öğretmenlere $(\bar{X}=3,8)$ göre daha yüksektir ancak aradaki fark anlamlı değildir $\left(\mathrm{t}_{(198)}=-0,266\right.$; p $>0,05)$. Kadın öğretmenler $(\bar{X}=3,2)$ erkek öğretmenlere $(\bar{X}=3,1)$ göre kazanımları öğrenci seviyesine daha çok uygun bulmaktadırlar ancak aralarındaki fark anlamlı değildir $\left(\mathrm{t}_{(198)}=-0,907\right.$; $\mathrm{p}>0,05)$. Kadın öğretmenler $(\bar{X}=2,2)$ erkek öğretmenlere $(\bar{X}=2,1)$ göre öğretim programını daha çok yeterli bulmaktadırlar ancak aralarındaki fark anlamlı değildir $\left(\mathrm{t}_{(198)}=-0,202 ; \mathrm{p}>0,05\right)$.

Kadın öğretmenler $(\bar{X}=3,6)$ erkek öğretmenlere $(\bar{X}=3,2)$ göre güvenlik ve güvenlik yazılımları konusuna daha çok yer vermektedirler ve aradaki bu fark istatistiki olarak anlamlıdır $\left(\mathrm{t}_{(198)}=-2,282 ; \mathrm{p}<0,05\right)$. Erkek öğretmenler $(\bar{X}=2,7)$ kadın öğretmenlere $(\bar{X}=2,2)$ göre öğrencilerin oyun oynamalarına daha çok izin vermektedirler ve aradaki bu fark istatistiki olarak anlamlı bulunmaktadır $\left(\mathrm{t}_{(198)}=3,052 ; \mathrm{p}<0,05\right)$. Erkek öğretmenler $(\bar{X}=3,9)$ kadın öğretmenlere $(\bar{X}=3,5)$ göre derslerde kısa filmlerden daha çok yararlanmaktadır ve aradaki bu fark anlamlı bulunmaktadır $\left(\mathrm{t}_{(198)}=-2,579 ; \mathrm{p}<0,05\right)$. Kadın öğretmenler $(\bar{X}=3,8)$ erkek öğretmenlere $(\bar{X}=3,2)$ göre siber suçlar konusuna daha çok yer vermektedirler ve aradaki bu fark istatistiki olarak anlamlı bulunmaktadır $\left(\mathrm{t}_{(198)}=-4,919 ; \mathrm{p}<0,05\right)$.

Sonuç olarak öğretmenlerin derslerinde yer verdikleri etkinlikler, yer verdikleri konular ve öğretim programlarında ilişkin görüşlerinin çoğunlukla benzer olduğu, ancak erkek öğretmenlerin derslerinde kısa film ve oyun etkinliklerine bayan öğretmenlere nazaran daha fazla yer verdikleri, bayan öğretmenlerin ise siber suçlar ve güvenlik konularına erkek öğretmenlerde daha fazla yer verdikleri söylenebilir.

Tablo 7.

Kazanımların Programa Uygunluğunun Mezun Olunan Fakülte Türüne Göre Fark1

\begin{tabular}{|c|c|c|c|c|c|c|c|}
\hline & & $\begin{array}{l}\text { Fakülte } \\
\text { Türü }\end{array}$ & $\overline{\mathrm{X}}$ & $\mathrm{S}$ & $\mathrm{sd}$ & $\mathrm{t}$ & $\mathrm{p}$ \\
\hline \multirow{16}{*}{$\begin{array}{l}\text { Dersinizde } \\
\text { genellikle ne tür } \\
\text { etkinliklere yer } \\
\text { veriyorsunuz? }\end{array}$} & \multirow{2}{*}{ Gösterip Yaptırma Yöntemi } & $\mathrm{EF}$ & 4,1 & 1,14 & 198 & ,244 & ,807 \\
\hline & & TEF & 4,0 & 1,07 & & & \\
\hline & \multirow{2}{*}{ Kisa Filmlerden Yararlanma } & EF & 3,8 & 1,06 & 198 & 3,565 & ,000 \\
\hline & & TEF & 3,1 & 1,10 & & & \\
\hline & \multirow{2}{*}{ Dersin Bilgisayarda İşlenmesi } & $\mathrm{EF}$ & 3,6 & 1,19 & 198 &,- 659 & ,511 \\
\hline & & TEF & 3,7 & 1,07 & & & \\
\hline & \multirow{2}{*}{ Kod Yazma Etkinlikleri } & EF & 2,9 & 1,30 & 198 &,- 243 & ,808 \\
\hline & & TEF & 3,0 & 1,30 & & & \\
\hline & \multirow{2}{*}{ Eğitsel Oyun Oynama } & $\mathrm{EF}$ & 2,8 & 1,16 & 198 & ,381 & ,703 \\
\hline & & TEF & 2,7 & 0,86 & & & \\
\hline & \multirow{2}{*}{ İstasyon Tekniğine Yer Verilmesi } & $\mathrm{EF}$ & 2,4 & 1,07 & 198 &,- 369 & ,713 \\
\hline & & TEF & 2,5 & 0,69 & & & \\
\hline & \multirow{2}{*}{ Dersin Teorik İşlenmesi } & $\mathrm{EF}$ & 2,4 & 1,12 & 198 & ,485 & ,628 \\
\hline & & TEF & 2,3 & 0,94 & & & \\
\hline & \multirow{2}{*}{ Oyun oynama } & EF & 2,4 & 1,23 & 198 &,- 741 & 460 \\
\hline & & TEF & 2,6 & 1,30 & & & \\
\hline
\end{tabular}


Bilişim Teknolojileri Öğretmenlerinin Derslerşinde Gerçekleştirdiği Etkinlikler, Bu Etkinliklerin Programa Uygunluğu ve Gerekçeleri

\begin{tabular}{|c|c|c|c|c|c|c|c|}
\hline & 3d Çizim Etkinlikleri & $\begin{array}{l}\text { EF } \\
\text { TFF }\end{array}$ & 1,8 & 1,06 & 198 & $-1,181$ & ,239 \\
\hline & \multirow{3}{*}{ Bilişim Teknolojileri Konusu } & & 2,0 & 1,03 & & & \\
\hline \multirow{18}{*}{$\begin{array}{l}\text { Derslerde hangi } \\
\text { konulara ağırlık } \\
\text { veriyorsunuz? }\end{array}$} & & EF & 4,0 & 0,79 & 198 &,- 113 & ,910 \\
\hline & & TEF & 4,1 & 0,69 & & & \\
\hline & \multirow{2}{*}{ Bilgisayar Kullanma Becerileri } & $\mathrm{EF}$ & 3,8 & 1,03 & 198 & $\begin{array}{l}-540 \\
\end{array}$ & ,590 \\
\hline & & TEF & 3,9 & 0,93 & & & \\
\hline & \multirow{2}{*}{ Office Programları } & $\overline{E F}$ & 3,7 & 1,03 & 198 & 1,432 & , 154 \\
\hline & & TEF & 3,5 & 0,98 & & & \\
\hline & \multirow{2}{*}{ Donanım Konusu } & $\mathrm{EF}$ & 3,7 & 0,92 & 198 & 1,390 & , 166 \\
\hline & & TEF & 3,4 & 0,76 & & & \\
\hline & \multirow{2}{*}{ Siber Suçlar Konusu } & $\mathrm{EF}$ & 3,6 & 0,93 & 198 & 3,400 & ,001 \\
\hline & & TEF & 3,0 & 0,98 & & & \\
\hline & \multirow{2}{*}{$\begin{array}{l}\text { Güvenlik ve Güvenlik Yazılımları } \\
\text { Konusu }\end{array}$} & $\mathrm{EF}$ & 3,5 & 0,98 & 198 & 3,331 & ,001 \\
\hline & & TEF & 3,0 & 0,98 & & & \\
\hline & \multirow{2}{*}{ Klavye Becerileri } & EF & 3,2 & 1,13 & 198 & $-1,259$ & ,209 \\
\hline & & TEF & 3,5 & 1,01 & & & \\
\hline & \multirow{2}{*}{$\begin{array}{l}\text { Algoritma ve Programlama } \\
\text { Konuları }\end{array}$} & EF & 2,9 & 1,21 & 198 & ,623 & ,534 \\
\hline & & TEF & 2,8 & 1,15 & & & \\
\hline & \multirow{2}{*}{ Scracth Konusu } & $\mathrm{EF}$ & 2,7 & 1,34 & 198 & 3,539 & ,001 \\
\hline & & TEF & 1,8 & 0,98 & & & \\
\hline \multirow{2}{*}{ Araç Gereç } & \multirow{2}{*}{ Araç Gereçlerin Mevcutluğu } & EF & 2,5 & 1,21 & 198 &,- 385 & ,701 \\
\hline & & TEF & 2,6 & 1,13 & & & \\
\hline \multirow{2}{*}{ İlgi } & \multirow[t]{2}{*}{ Öğrencilerin Derse İlgisi } & $\mathrm{EF}$ & 3,9 & 0,84 & 198 & 2,654 & ,009 \\
\hline & & TEF & 3,5 & 0,86 & & & \\
\hline \multirow{8}{*}{ Öğretim programı } & \multirow{2}{*}{ Derslerin Kazanımlara Uygunluğu } & EF & 3,7 & 0,98 & 198 & 1,009 & 314 \\
\hline & & TEF & 3,5 & 0,86 & & & \\
\hline & \multirow{2}{*}{$\begin{array}{l}\text { Kazanımların Bulunduğumuz } \\
\text { Çağa Uygunluğu }\end{array}$} & $\mathrm{EF}$ & 3,3 & 1,03 & 198 & $-2,001$ & 047, \\
\hline & & TEF & 3,6 & 0,97 & & & \\
\hline & \multirow{2}{*}{$\begin{array}{l}\text { Kazanımların Öğrenci Seviyesine } \\
\text { Uygunluğu }\end{array}$} & $\mathrm{EF}$ & 3,1 & 0,95 & 198 & 1,033 & ,303 \\
\hline & & TEF & 3,0 & 0,70 & & & \\
\hline & \multirow{2}{*}{ Öğretim programının Yeterliliği } & EF & 2,1 & 0,95 & 198 &,- 244 & 807 \\
\hline & & TEF & 2,2 & 0,87 & & & \\
\hline
\end{tabular}

*N (Eğitim Fakültesi=163, Teknik Eğitim Fakültesi=37)

Ders etkinliklerinin öğretmenlerin mezun oldukları fakülte türü arasında farklılık gösterip göstermediğini anlamak için bağımsız örneklem $t$ testi yapılmıştır. Analiz sonuçlarına göre eğitim fakültesinden mezun öğretmenlerin $(\bar{X}=2,4)$ teknik eğitim fakültesi mezunu ögrretmenlere $(\bar{X}=2,3)$ göre dersi daha çok teorik olarak işledikleri görülmektedir ancak fark anlamlı değildir $\left(\mathrm{t}_{(198)}=0,485 ; \mathrm{p}>0,05\right)$. Teknik eğitim fakültesi mezunu öğretmenler $(\bar{X}=3,7)$ eğitim fakültesi mezunu öğretmenlere $(\bar{X}=3,6)$ göre dersi daha çok bilgisayarda işlenmektedirler ancak fark anlamlı değildir. $\left(\mathrm{t}_{(198)}=-0,659 ; \mathrm{p}>0,05\right)$. Teknik eğitim fakültesi mezunu öğretmenler $(\bar{X}=2,5)$ eğitim fakültesi mezunu öğretmenlere $(\bar{X}=2,4)$ göre İstasyon tekniğine daha çok yer vermektedirler ancak fark anlamlı değildir $\left(t_{(198)}=-, 369 ; p>0,05\right)$. Eğitim fakültesi mezunu öğretmenler $(\bar{X}=4,1)$ teknik eğitim fakültesi mezunu öğretmenlere $(\bar{X}=4,0)$ göre gösterip yaptırma yöntemine daha fazla yer vermektedirler ancak aradaki bu fark anlaml değildir $\left(\mathrm{t}_{(198)}=0,244 ; \mathrm{p}>0,05\right)$. Eğitim fakültesi mezunu öğretmenler $(\bar{X}=3,0)$ eğitim fakültesi mezunu öğretmenlere $(\bar{X}=2,9)$ göre kod yazma etkinliklerine daha çok yer vermektedirler ancak fark anlamlı değildir $\left(\mathrm{t}_{(198)}=-0,243 ; \mathrm{p}>0,05\right)$. Teknik eğitim fakültesi mezunu öğretmenler $(\bar{X}=$ 2,0) eğitim fakültesi mezunu öğretmenlere $(\bar{X}=1,8)$ göre $3 \mathrm{~d}$ çizim etkinliklerine daha çok yer vermektedir ancak aradaki bu fark anlamlı değildir $\left(\mathrm{t}_{(198)}=-1,181 ; \mathrm{p}>0,05\right)$. Eğitim fakültesi mezunu ögretmenler $(\bar{X}=3,7)$ teknik eğitim fakültesi mezunu öğretmenlere $(\bar{X}=3,5)$ göre Office programlarına daha çok yer vermektedir ancak aradaki bu fark anlamlı değildir $\left(\mathrm{t}_{(198)}=-1,432\right.$; 
$\mathrm{p}>0,05)$. Teknik eğitim fakültesi mezunu öğretmenler $(\bar{X}=3,5)$ eğitim fakültesi mezunu öğretmenlere $(\bar{X}=3,2)$ göre klavye becerileri eğitimine daha çok yer vermektedirler ancak fark anlamlı değildir $\left(\mathrm{t}_{(198)}=-1,259 ; \mathrm{p}>0,05\right)$. Teknik eğitim fakültesi mezunu öğretmenler $(\bar{X}=4,1)$ eğitim fakültesi mezunu öğretmenlere $(\bar{X}=4,0)$ göre bilişim teknolojileri konusuna daha çok yer vermektedirler ancak fark anlamlı değildir $\left(\mathrm{t}_{(198)}=-0,113 ; \mathrm{p}>0,05\right)$. Eğitim fakültesi mezunu öğretmenler $(\bar{X}=3,7)$ teknik eğitim fakültesi mezunu öğretmenlere $(\bar{X}=3,4)$ göre donanım konusuna daha çok yer vermektedirler ancak fark larak anlamlı değildir $\left(t_{(198)}=1,390 ; p>0,05\right)$. Teknik eğitim fakültesi mezunu öğretmenler $(\bar{X}=3,9)$ eğitim fakültesi mezunu öğretmenlere $(\bar{X}=3,8)$ göre bilgisayar kullanma becerileri eğitimine daha fazla yer vermektedirler ancak aralarındaki fark anlamlı değildir $\left(\mathrm{t}_{(198)}=-0540 ; \mathrm{p}>0,05\right)$. Eğitim fakültesi mezunu öğretmenler $(\bar{X}=2,9)$ teknik eğitim fakültesi mezunu öğretmenlere $(\bar{X}=2,8)$ göre algoritma ve programlama konularına daha çok yer vermektedirler ancak aralarındaki fark anlamlı değildir $\left(t_{(198)}=0,623\right.$; $\mathrm{p}>0,05)$. Teknik eğitim fakültesi mezunu öğretmenler $(\bar{X}=2,6)$ eğitim fakültesi mezunu öğretmenlere $(\bar{X}=2,4)$ göre öğrencilerin oyun oynamalarına daha çok izin vermektedirler ancak aradaki fark anlamlı değildir $\left(\mathrm{t}_{(198)}=-0,741 ; \mathrm{p}>0,05\right)$. Eğitim fakültesi mezunu öğretmenler $(\bar{X}=$ $2,8)$ teknik eğitim fakültesi mezunu öğretmenlere $(\bar{X}=2,7)$ göre öğrencilerin sadece eğitsel oyun oynamalarına daha çok izin vermektedirler ancak fark anlamlı değildir $\left(\mathrm{t}_{(198)}=0,381 ; \mathrm{p}>0,05\right)$. Eğitim fakültesi mezunu öğretmenler $(\bar{X}=3,7)$ teknik eğitim fakültesi mezunu öğretmenlere $(\bar{X}=$ $3,5)$ göre etkinlikleri daha çok programa uygun yapmaktadırlar ancak fark anlamlı değildir $\left(\mathrm{t}_{(198)}=1,009 ; \mathrm{p}>0,05\right)$. Teknik eğitim fakültesi mezunu öğretmenler $(\bar{X}=2,6)$ eğitim fakültesi mezunu öğretmenlere $(\bar{X}=2,5)$ göre sınıflarında gerekli araç gereçleri daha çok yeterli bulmaktadırlar ancak aradaki bu fark anlamlı değildir $\left(t_{(198)}=0,385 ; p>0,05\right)$. Eğitim fakültesi mezunu öğretmenler $(\bar{X}=3,1)$ teknik eğitim fakültesi mezunu öğretmenlere $(\bar{X}=3,0)$ göre kazanımları öğrenci seviyesine daha uygun bulmaktadırlar ancak aralarındaki fark anlamlı değildir $\left(\mathrm{t}_{(198)}=1,033 ; \mathrm{p}>0,05\right)$. Teknik eğitim fakültesi mezunu öğretmenler $(\bar{X}=2,2)$ eğitim fakültesi mezunu öğretmenlere $(\bar{X}=2,1)$ göre öğretim programını daha çok yeterli bulmaktadırlar ancak aralarındaki fark anlamlı değildir $\left(\mathrm{t}_{(198)}=-0,244 ; \mathrm{p}>0,05\right)$.

Eğitim fakültesi mezunu öğretmenler $(\bar{X}=3,5)$ teknik eğitim fakültesi mezunu ögrretmenlere $(\bar{X}=3,0)$ göre güvenlik ve güvenlik yazılımları konusuna daha çok yer vermektedirler ve aradaki bu fark anlamlıdır $\left(\mathrm{t}_{(198)}=3,331 ; \mathrm{p}<0,05\right)$. Eğitim fakültesi mezunu ögretmenler $(\bar{X}=2,7)$ teknik eğitim fakültesi mezunu öğretmenlere $(\bar{X}=1,8)$ göre scracth konusuna daha çok yer vermektedirler ve aralarındaki fark anlamlıdır $\left(\mathrm{t}_{(198)}=-3,539 ; \mathrm{p}<0,05\right)$. Teknik eğitim fakültesi mezunu öğretmenler $(\bar{X}=3,6)$ eğitim fakültesi mezunu öğretmenlere $(\bar{X}=3,3)$ göre kazanımların bulunduğumuz çağa uygun olduğunu daha çok ileri sürmektedirler ve aralarındaki fark anlamlıdır $\left(\mathrm{t}_{(198)}=-2,001 ; \mathrm{p}<0,05\right)$. Eğitim fakültesi mezunu öğretmenler $(\bar{X}=$ $3,9)$ teknik eğitim fakültesi mezunu öğretmenlere $(\bar{X}=3,5)$ göre sınıfındaki öğrencilerin derse karşı olan ilgilerini daha yüksek bulmaktadırlar ve aradaki bu farkın anlamlıdır $\left(\mathrm{t}_{(198)}=2,654\right.$; $\mathrm{p}<0,05)$. Eğitim fakültesi mezunu öğretmenler $(\bar{X}=3,8)$ teknik eğitim fakültesi mezunu ögrretmenlere $(\bar{X}=3,1)$ göre derslerde kısa filmlere daha çok yer vermektedirler aradaki bu fark anlamlı bulunmaktadır $\left(\mathrm{t}_{(198)}=3,565 ; \mathrm{p}<0,05\right)$. Eğitim fakültesi mezunu öğretmenler $(\bar{X}=3,6)$ teknik eğitim fakültesi mezunu öğretmenlere $(\bar{X}=3,0)$ göre siber suçlar konusuna daha çok yer vermektedirler ve aradaki bu fark anlamlı bulunmaktadır $\left(\mathrm{t}_{(198)}=-3,400 ; \mathrm{p}<0,05\right)$.

Sonuç olarak öğretmenlerin derslerinde yer verdikleri etkinlikler, yer verdikleri konular ve öğretim programlarında ilişkin görüşlerinin genellikle benzer olduğu, ancak eğitim fakültesi mezunu öğretmenlerin derslerinde güvenlik, siber suçlar, scracth konusu ve kısa film etkinliklerine yer vermektedirler ve öğrencilerin derse olan ilgilerini yüksek bulmaktadırlar. 
Teknik eğitim fakültesi mezunu öğretmenlerin ise eğitim fakültesi mezunu öğretmenlere nazaran kazanımları bulunduğumuz çağa uygun buldukları söylenebilir.

\section{Sonuç ve Tartışma}

$\mathrm{Bu}$ araştırmadan elde edilen sonuçlara göre Bilişim Teknolojileri öğretmenlerinin sınıflarında gerçekleştirdiği etkinlikler çoğunlukla programdaki kazanımlara uymakla birlikte kazanımların öğrenci seviyelerine göre yetersiz olduğu söylenebilir. Bu yetersizliğin alan yazında birçok örneğine rastlamak mümkündür (Henkoğlu ve Yıldırım, 2012; Kural ve Güven, 2008; Topu, 2010). Wagner ve diğerleri (2005) Bilgi ve bilgisayar teknolojilerinin eğitime sağladığı katkılar fazla olsa da bu alanda yapılan yanlış uygulamalar, planlamalar ve eğitim politikaları hem yapılan yatırımların maliyetini artırmakta hem de uygulama alanında istenilen sonuçları verememektedir, diyerek teknolojinin planlanmasını uygulanacak alanlara göre yapmanın önemini vurgulamışlardır. Bu araştırmada elde edilen veriler doğrultusunda programın öğrenci seviyesine uygunluğu konusunda öğretmenlerin tereddütleri olduğu görülmüştür. Öğretmenlerin gerçekleştirdikleri etkinliklerin programa uygunluğu cinsiyet, mezun olunan fakülte ve okulun bulunduğu bölgeye göre değişim göstermediği fakat öğretmenlik mesleğindeki yıl arttıkça gerçekleştirilen etkinliklerin programa uygun olduğu görülmektedir. Öğretmenlerden toplanan verilerde göze çarpan bir başka yetersizlik ise okulların teknik açıdan kısıtlı olması ve dersin kazanımlarına uygun teknik aletlerin bulunmamasıdır. Bu sonuç alan yazınla da tutarlılık göstermektedir (Gülcü, Aydın ve Aydın, 2013; Karal, Reisoğlu ve Günaydın, 2010; Topu, 2010). Örneğin Gülcü, Aydın ve Aydın (2013) 290 BT öğretmeni ile yaptıkları İlköğretim Okullarında Bilişim Teknolojileri Dersi Yeni Öğretim Programının Öğretmen Görüşlerine Göre Değerlendirilmesi adlı çalışmalarında bilişim teknolojileri öğretmenleri dersin işlenmesinde donanım sorunu yaşadıklarını ve laboratuvardaki bilgisayarların yetersiz kaldığını ifade etmişlerdir. Yine Karal, Reisoğlu ve Günaydın (2010) 150 BT öğretmeni ile yaptıkları İlköğretim Bilişim Teknolojileri Ders Öğretim Programının Değerlendirilmesi aslı çalışmalarında ögretmenler, öğretim programın ideal sınıf ortamı için hazırlandığını, kendi okullarında öğretim programında belirtilen etkinliklerin gerçekleştirilmesi için yeterli teknolojinin olmadığını belirtmektedirler. Topu (2010) benzer şekilde, çalışmasında öğretmenlerin sürekli oluşan teknik aksaklıklar ve bilgisayarların yetersiz oluşundan dolayı derslerinde verimliliğin azaldığını belirttiklerini ifade etmektedir. Granger, Morbey, Lotherington, Owston ve Wideman (2002) ise bilişim teknolojilerinin eğitimde başarılı uygulamalarını araştıran çalışmalarında dersin işlenebilmesi için gerekli materyallerin olmaması durumunda verimli öğrenmenin gerçekleşmeyeceği, bu durumda hem öğrenci hem de öğretmenlerin derse karşı olumsuz tutumlara sahip olacağı belirtilmektedir. Bu durum kazanımların gerçekleştirilmesinin eksiklikler nedeni ile olumsuz yönde etkilendiği sonucunu ortaya koymaktadır.

Öğretmenlerin cinsiyetlerine bağl1 olarak da derste gerçekleştirilen etkinliklerin benzer olduğu görülmektedir ancak kadın öğretmenlerin öğretim programına daha uygun ders işledikleri görülürken erkek öğretmenlerin öğretim programı dışına çıktıkları da elde edilen bulgular arasındadır. Benzer şekilde Kural Er ve Güven (2008) tarafından yapılan çalışmada da öğretmenlerin öğretim programıta belirtilen içeriğin dışına çıktıkları belirtilmiştir. Ayrıca kadın öğretmenlerin ders verdiğin öğrencilerin derse karşı olan ilgileri erkek öğretmenlerin ders verdiği öğrencilerin derse karşı olan ilgilerinden fazla olduğu da görülmektedir. Yine kadın öğretmenler öğretim programını yeterli bulurken erkek öğretmenler için öğretim programı yeterli görülmemiştir. Bu sonuçlara göre kadın öğretmenler öğrencilere dersi sevdirmenin yanı sıra öğretim programı içerisinde yer alan konuları da yeterli bularak derslerini işlemektedirler. Bilişim Teknolojileri dersinin öğrenciler tarafından sevildiği de verilerden elde edilen sonuçlar arasındadır. BT derslerinin sevilmesinde etkinliklerin yanı sıra öğrencilerin bu dersi oyun oynama dersi olarak gördükleri de söylenebilir. Bilgisayarı bir oyun aracı olarak görmeleri ve oyun oynama isteklerinin öğretmenler tarafindan ve ders açısından bir problem ortaya çıkardığ 1 görülmektedir. Yeşiltepe ve Erdoğan'ın (2013) İlköğretim Bilişim Teknolojileri Öğretmenlerinin Mesleğe Yönelik Sorunlarını inceledikleri çalışmada, öğretmenlerin disiplin 
problemlerinin temel nedenleri arasında öğrencilerin bilgisayarı oyun aracı olarak gördükleri ifade edilmektedir. Bu ifadeden de yola çıkarak bu sorunun BT eğitiminde büyük önem taşıdığ söylenebilir.

Öğretmenlerin kodlama ve programlama konularına pek önem vermedikleri ancak temel konulara yoğunlaştıkları görülmektedir. Oysaki programlama eğitimi erken yaşlardan itibaren üzerinde durulması gereken konulardandır. Programlama becerisi, bireyin üst düzey düşünme becerilerinin gelişimine katkı sağlamakla beraber, bir problemin çözümünde olasılıklı ve sistemli düşünmeyi sağlamaktadır. Günümüzde özellikle çocuklara yönelik olarak geliştirilen programlar ile programlamayı görselleştirerek ve basite indirgeyerek çocukların ilgisini çekmek amaçlanmaktadır. Örneğin Kaucic ve Asic (2011) tarafından yapılan çalışmada, görsel araçlarla programlama eğitimi alan öğrencilerin problem çözme ve eleştirel düşünme becerilerinde olumlu yönde artış olduğu ortaya çıkmıştır. Bilişim teknolojileri ve Yazılım Dersi öğretim programı incelendiğinde 5 . ve 6 . Sinıflarda programlama dersine 36 ayrıldığ görülmektedir (TTKB, 2018). Öğretim programıta dersin yarısının programlamaya ayrılmasına rağmen öğretmenlerin programlama eğitimine önem vermemeleri tezat bir durum ortaya koymaktadır. Temel konuların yanı sıra öğrencilerin günümüz teknoloji dünyasında zaman zaman maruz kaldıkları siber suçlar konusuna da yer verdikleri görülmektedir. Bunun yanı sıra güvenlik yazılımları konusunda da öğretmenlerin hassas davrandıkları ve bu konulara önem verdikleri görülmektedir. Gökmen ve Akgün (2015) tarafından yürütülen çalışmada öğrencilerin bilişim teknolojilerini ve interneti kullanırken karşılaşabilecekleri güvenlik sorunlarına karşı nasıl korunacaklarının önemine vurgu yapmışlardır.

Sonuç olarak Bilişim Teknolojileri dersi içeriğinin teknolojik ve toplumsal gelişmeler doğrultusunda genişletilmesi ve dersin işleneceği laboratuvarların daha iyi hale getirilmesi gerekmektedir. Bu derse ve dersin öğretmenlerine karşı olan tutumların değiştirilmesi, bu derse verilen önemin artması toplum yararına olacaktır.

\section{Öneriler}

- Derslerde gerçekleştirilen etkinliklerin programa uygun olması ve bu etkinliklerden istenilen verimin alınması için altyapı ve araç gereç eksikliklerinin bütün bölgelerde giderilmesi sağlanmalıdır veya öğretim programları mevcut durumlara göz önünde bulundurularak düzenlenmelidir.

- Programın öncelikle hedeflenen içerikler doğrultusunda yeniden düzenlenmesi ve öğrenci gelişimlerine uygun olarak oluşturulması daha verimli bir ders ortaya çıkmasını sağlayabilir.

- Öğretmenlerin programlama eğitimi konusunda geliştirilmesi için güncel programlama araçlarına ilişkin hizmet içi eğitimler verilebilir.

- Scratch, lego, code.org gibi görsel programlama araçları ile öğrencilere programlama eğitimi sevdirilebilir.

\section{Kaynaklar}

Akbıyık, C. ve Seferoğlu, S. S. (2012). İlköğretim bilişim teknolojileri dersinin işlenişi: Öğretmen görüş ve uygulamaları. Kuram ve Uygulamada Eğitim Bilimleri, 12(1), 405424.

Akkoyunlu, B. ve Kurbanoğlu S. (2003). Öğretmen adaylarinin bilgi okuryazarliği ve bilgisayar öz-yeterlik algilari üzerine bir çalişma. Hacettepe Üniversitesi Eğitim Fakültesi Dergisi, 24, $1-10$.

Büyükköztürk, Ş., Kılıç Çakmak, E., Akgün, E. Ö., Karadeniz, Ş. ve Demirel, F. (2016). Bilimsel araştirma yöntemleri. Ankara: Pegem Akademi.

Cakir, R. ve Yıldırım, S. (2015). Who are they really? A Review of the characteristics of preservice ICT teachers in Turkey. The Asia-Pacific Education Researcher, 24(1), 67-80. doi. 10.1007/s40299-013-0159-9 
Çengel, M. (2007). İlköğretim dördüncü sınıf bilgisayar dersi programının değerlendirilmesi. (Yayımlanmamış yüksek lisans tezi). Adnan Menderes Üniversitesi, Aydın.

Eren, E. ve Uluuysal, B. (2012). Bilişim teknolojileri (BT) öğretmenlerinin mesleki sorunları ve çözüm önerileri: Okul müdürü ve BT öğretmenlerinin görüşleri. Mersin Üniversitesi Ĕgitim Fakültesi Dergisi, 8(3), 152-171.

Fahnoe C. ve Mishra P. (2013). Do 21st century learning environments support self-directed learning? Middle school students' response to an intentionally designed learning environment. Proceedings of Society for Information Technology \& Teacher Education International Conference, içinde (ss. 3131-3139).

Fırat Durdukoca, Ş. ve Arıbaş, S. (2011). Ilköğretim seçmeli bilişim teknolojileri dersi 5. Basamak öğretim programinin öğretmen görüşleri doğrultusunda değerlendirilmesi (Malatya İli örneği). Yüzüncü Yll Üniversitesi, Eğitim Fakültesi Dergisi, 8(1), 140-168.

Gil-Flores, J., Rodríguez-Santero, J. ve Torres-Gordillo, J. J. (2017). Factors that explain the use of ICT in secondary-education classrooms: The role of teacher characteristics and school infrastructure. Computers in Human Behavior, 68, 441-449.

Gökmen, Ö. F. ve Akgün, Ö. E. (2015). Bilgisayar ve öğretim teknolojileri eğitimi öğretmen adaylarının bilişim güvenliği eğitimi verebilmeye yönelik yeterlilik algılarının incelenmesi. Illkögretim Online, 14(4), 1208-1221.

Granger, C. A., Morbey, M. L., Lotherington, H., Owston, R. D. ve Wideman, H. H. (2002). Factors contributing to teachers' successful implementation of IT. Journal of Computer Assisted Learning, 18, 480-488.

Gülcü, A., Aydın, S. ve Aydın, Ş. (2013). İlköğretim okullarinda bilişim teknolojileri dersi yeni öğretim programinin öğretmen görüşlerine göre değerlendirilmesi. Karadeniz Sosyal Bilimler Dergisi, 5(8), 73-92.

Henkoğlu, H. Ş. ve Yıldırım, S. (2012). Türkiye'deki ilköğretim okullarinda bilgisayar eğitimi: Kuram ve uygulamadaki farkl1lıklar. Journal of Faculty of Educational Sciences, 45(1), 23-61.

ISTE (2014). ISTE standarts for students. Erişim adresi: http://www.iste.org/standards/istestandards/standards-for-students

Kabakçı, I., Kurt, A. ve Yıldırım Y. (2008). Bilgisayar öğretmenlerinin seçmeli bilişim teknolojileri öğretim programının uygunluğuna ilişkin görüşlerinin belirlenmesi. 8 . Uluslararası Ĕ̈itim Teknolojileri Konferansı, içinde (ss. 518-526).

Karal, H., Reisoğlu, İ. ve Günaydın, E. (2010). İlköğretim bilişim teknolojileri dersi öğretim programinin değerlendirilmesi. Cukurova University Faculty of Education Journal, 38(3), 46-64.

Kaucic, B. ve Asic, T. (2011). Improving introductory programming with Scratch? Proceeding of the 34th MIPRO International Conference, içinde (ss. 1095-1100).

Kural Er, F. ve Güven, B. (2008). İlköğretim 6, 7 ve 8. Sinıf bilgisayar dersi programının içeriğine ilişkin öğretmen görüşleri. Sosyal Bilimler Dergisi, 19, 175-184.

Kurt, A. A., Kuzu, A., Dursun, Ö. Ö., Güllüpınar, F. ve Gültekin, M. (2013) FATİH projesinin pilot uygulama sürecinin değerlendirilmesi: Öğretmen görüşleri. Journal of Instructional Technologies \& Teacher Education, 2(1), 1-23.

Law, N. ve Plomp, T. (2003). Curriculum and staff development for ICT in Education. T. Plomp, R., Anderson, N. Law ve A. Quale (Yay. haz.). Cross-national information and communication technology policies and practices in education, içinde (ss. 15-31). Greenwich: Connecticut: IAP.

Lee, Y. ve Lee, J. (2014). Enhancing pre-service teachers' self-efficacy beliefs for technology integration through lesson planning practice. Computers \& Education, 73, 121-128.

Mishra, P. ve Koehler, M. J. (2009). Teachers' technological pedagogical content knowledge and learning activity types: Curriculum-based technology integration reframed. Journal of Research on Technology in Education, 41(4), 393-416. 
Orhan, F. ve Akkoyunlu, B. (2003). Eğitici Bilgisayar formatör (master) öğretmenlerin profilleri ve uygulamada karşılaştıkları güçlüklere ilişkin görüşleri. Hacettepe Üniversitesi Eğitim Fakültesi Dergisi, 24, 90-100.

Sykora, C. (2014). Computational thinking for all. Erişim adresi: https://www.iste.org/explore/ articleDetail ?articleid $=152 \&$ category=Solutions\&article $=$ Computational-thinking-for-

Tondeur, J., Aesaert, K., Prestridge, S. ve Consuegra, E. (2018). A multilevel analysis of what matters in the training of pre-service teacher's ICT competencies. Computers and Education, 122, 32-42.

Topu, B. F. (2010). Bilişsim teknolojileri ögretmenlerinin okullarındaki rolleri, beklentiler ve karşılaşılan problemler: Erzurum ili örneği (Yayımlanmamış yüksek lisans tezi). Atatürk Üniversitesi. Erzurum.

Topu, B. F. ve Göktaş, Y. (2012). Bilişim teknolojileri öğretmenlerinin üstlendikleri roller ve onlardan beklentiler. Kuram ve Uygulamada Eğitim Bilimleri, 12(1), 461-478.

TTKB. (2016). Illkögretim kurumları ilkokullar ve ortaokullar haftallk ders çizelgesi. Erişim adresi: http://ttkb.meb.gov.tr/www/haftalik-ders-cizelgeleri/dosya/6

TTKB. (2018). Bilişim teknolojileri ve yazılım dersi öğretim programı (Ortaokul 5 ve 6. Sinıf). Erişim adresi: http://ttkb.meb.gov.tr/www/haftalik-ders-cizelgeleri/dosya/6

TÜíK. (2016). Hane halkı bilişim teknolojileri kullanım araştırması. Erişim adresi: http://www.tuik.gov.tr/PreHaberBultenleri.do?id=21779

Wagner, D. A., Day, B., James, T., Kozma, R. B., Miller, J. ve Unwin, T. (2005). Monitoring and evaluation ICT in education projects $-A$ handbook for developing countries. Washington D.C.: The International Bank for Reconstruction and Development / The World Bank.

Yeşiltepe, G. M. ve Erdoğan, M. (2013). İlköğretim bilişim teknolojileri öğretmenlerinin mesleğe yönelik sorunları, bu sorunların nedenleri ve çözüm önerileri. Gazi Üniversitesi Gazi Ĕ̈itim Fakültesi Dergisi, 33(3), 495-530.

\section{Extended Abstract}

\section{Introduction}

Information Technology (IT) courses are taught as an elective course in the 5th and 6th grades, and mandatory in the 6th and 7th grades in the curriculum, Doubtlessly, the effectiveness of these courses depends not only on the equipment situation in the schools but also on the activities the teachers' performs. It is expected that IT courses will be taught in the curriculum as theoretical, practical and cooperative learning (TTKB, 2016). In order for the curriculum to be successful, it can be said that what kind of activities are carried out by IT teachers and it is important that these activities are appropriate for the curriculum. In a study conducted by Akbıyık and Seferoğlu (2012), teachers ask students to practice after explaining the subject by projection, or likewise ask students to practice taking into account the instructions in the work sheets or textbook. Based on the results of the study conducted by Kural Er and Güven (2008), teachers agreed that the acquisations of the computer course are not in line with the developments and changes in technology and the interests, needs and readiness of the students taking this course, therefore, they followed different programs in their computer courses than the usual curriculum. Topu and Göktaş (2012) conducted face-to-face interviews with IT teachers in their studies. According to the results of their study, teachers stated that they were step out of the curriculum and teach in a more comprehensible manner, the course is perceived as a game and the teacher is seen as a repairman.

In order for these IT courses to be effective, there is a constant debate on the extent to which teachers are applying the program, whether the curriculum prepared by the Ministry of Education are adequate according to the technology, whether there are appropriate opportunities for the school to carry out the program, and whether the teachers use the available opportunities effectively. Moreover, in the study conducted by Çengel (2007), it has been revealed that the 
physical environment and sub-structure of the computer labs in the schools are important for the learning and teaching processes and there is no consensus among the teachers on computer coursebooks. Similarly, it has been determined that the teachers have positive opinions about the acquisition and evaluation stages of the teaching program but they do not have a definite opinion about the content of the program and the teaching-learning processes (Kabakç1, Kurt and Yildirim (2008). In this study, it is aimed to determine whether teachers are compatible with the curriculum within the course, whether there is any difference between the courses taught by the teachers and the curriculum and the reason for this differentiation. Teacher's experience is the factor used to determine whether the content of the lessons is a standard or to see if this experience has become more innovative, and the area where the school located how different possibilities in different settlements affected the course activities.

\section{Method}

The survey method was used in this study. In this context, the activities carried out by the information technology teachers in their classrooms, the appropriateness of these activities to the curriculum and their justifications were investigated. The sample of the study constitutes 101 women and 99 men, a total of 200 secondary schools' IT teachers who were randomly selected from various provinces of Turkey.

In the study, "Teaching Processes of Information Technology Teachers" questionnaire was used as the data collection tool. This questionnaire was prepared to determine the IT teachers' activities in information technologies courses and their views towards this course. During the preparation of the questionnaire, 10 open-ended questions were asked to IT teachers. In the creation of these questions, expert opinions were taken into consideration and the questions were finalized according to the opinions of the experts. Twenty IT teachers responded to these questions and the opinions obtained were converted into items. Cronbach's alpha internal consistency coefficient of the questionnaire was found to be 0,723 .

\section{Result and Discussion}

Analysis of the data obtained in the study was tested through SPSS 20 package program. In the analysis of the data; mean, frequency, standard deviation, pearson correlation, independent sample $\mathrm{t}$ test and anova analysis were used. According to the results, the activities of the Information Technology teachers in their classes mostly correspond to the learning outcomes in the curriculum, but it can be said that the outcomes are insufficient according to the students' levels. According to the data obtained in this study, it was seen that teachers had hesitations about the suitability of the program to student level. In addition, the results showed that teachers have hesitations about the suitability of the curriculum to the students' level. It can be seen that the appropriateness of activities of the teachers to the program do not change according to the gender, the graduated faculty and the region where the school is located but the activities performed as the year increases in the teaching profession are appropriate for the program. One of the other insufficiencies is that the schools are technically limited and there is not enough technical equipment suitable for the course learning outcomes. Depending on the gender differences of the teachers, it is seen that the activities carried out are similar, but the female teachers are more likely to study in curriculum more appropriately, while male teachers work out of the curriculum. Teachers do not seem to pay much attention to coding and programming, but they seem to focus on the main issues. In this context, the following can be suggested: in order to ensure that the activities carried out in the lessons are appropriate to the program and to obtain the desired efficiency from these activities, the lack of infrastructure and equipment must be eliminated in all regions. In addition, the curriculum may be arranged taking into consideration the current situations. Reorganization of the program primarily in line with the targeted content and creation of in accordance with student's development can lead to a more productive lesson. Moreover, in-service training on current programming tools can be given for the development of teachers in programming education. Students can enjoy programming education with visual programming tools such as scratch, lego and code.org. 